\title{
Munidopsis species (Crustacea: Decapoda: Munidopsidae) from carcass falls in Weijia Guyot, West Pacific, with recognition of a new species based on integrative taxonomy
}

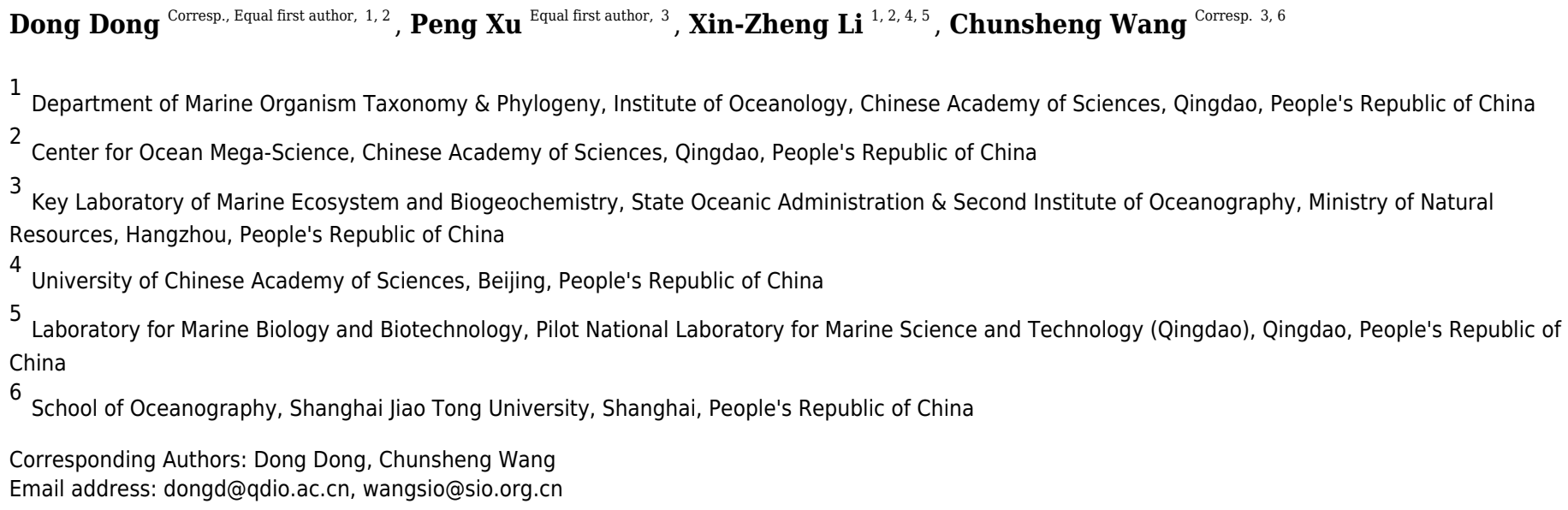

Several squat lobster specimens of the genus Munidopsis were collected from an artificially placed carcass fall (cow bones) on Weijia Guyot in the western Pacific Ocean. Based on morphological comparisons and molecular analysis, three specimens were confirmed as juveniles of $M$. albatrossae Pequegnat \& Pequegnat, 1973, which represents the first record of this species in the western Pacific. The other specimens collected are newly described as Munidopsis spinifrons sp. nov., which is distinguished from the closely related species in having a spinose rostrum and basal lateral eyespine on the eyestalk. The $M$. albatrossae from Weijia Guyot exhibited very low genetic distances when compared with a conspecific sample from Monterey Bay, USA, and the closely related species $M$. aries (A. Milne Edwards, 1880) from the northeastern Atlantic. A phylogenetic tree based on the mtCOI gene shows $M$. spinifrons sp. nov. as sister to $M$. vrijenhoeki Jones \& Macpherson, 2007 and M. nitida (A. Milne Edwards, 1880), although M. vrijenhoeki presents a complex relationship with other species in the clade. The systematic status of the new species and the closely related species are discussed. 
1 Munidopsis species (Crustacea: Decapoda: Munidopsidae)

2 from carcass falls in Weijia Guyot, West Pacific, with

3 recognition of a new species based on integrative taxonomy

5 Dong Dong ${ }^{1,2, *}$, Peng $\mathrm{Xu}^{3, *}$, Xinzheng $\mathrm{Li}^{1,2,4,5}$, Chunsheng Wang ${ }^{2,6}$

$7{ }^{1}$ Department of Marine Organism Taxonomy \& Phylogeny, Institute of Oceanology, Chinese

8 Academy of Sciences, Qingdao, China

$9{ }^{2}$ Center for Ocean Mega-Science, Chinese Academy of Sciences, Qingdao, China

$10{ }^{3}$ Key Laboratory of Marine Ecosystem and Biogeochemistry, State Oceanic Administration \&

11 Second Institute of Oceanography, Ministry of Natural Resources, Hangzhou, China

$12{ }^{4}$ University of Chinese Academy of Sciences, Beijing, China

$13{ }^{5}$ Laboratory for Marine Biology and Biotechnology, Pilot National Laboratory for Marine

14 Science and Technology (Qingdao), Qingdao, China

$15{ }^{6}$ School of Oceanography, Shanghai Jiao Tong University, Shanghai, China

$16 *$ These authors contributed equally to this work.

Corresponding authers:

Dong Dong,

7 Nanhai Road, Qingdao, 266071, China.

dongd@qdio.ac.cn;

Chunsheng Wang,

36 Baochubei Road, Hangzhou, 310012, China

wangsio@sio.org.cn 
26

27

\section{Abstract}

Several squat lobster specimens of the genus Munidopsis were collected from an artificially placed carcass fall (cow bones) on Weijia Guyot in the western Pacific Ocean. Based on morphological comparisons and molecular analysis, three specimens were confirmed as juveniles of M. albatrossae Pequegnat \& Pequegnat, 1973, which represents the first record of this species in the western Pacific. The other specimens collected are newly described as Munidopsis spinifrons sp. nov., which is distinguished from the closely related species in having a spinose rostrum and basal lateral eyespine on the eyestalk. The M. albatrossae from Weijia Guyot exhibited very low genetic distances when compared with a conspecific sample from Monterey Bay, USA, and the closely related species M. aries (A. Milne Edwards, 1880) from the northeastern Atlantic. A phylogenetic tree based on the mtCOI gene shows M. spinifrons sp. nov. as sister to M. vrijenhoeki Jones \& Macpherson, 2007 and M. nitida (A. Milne Edwards, 1880), although M. vrijenhoeki presents a complex relationship with other species in the clade. The systematic status of the new species and the closely related species are discussed.

Subjects: Taxonomic study of squat lobsters from a deep-sea carcass fall

Keywords: Munidopsis, carcass fall, Weijia Guyot, new species, molecular phylogeny 


\section{Introduction}

The genus Munidopsis Whiteaves, 1874 comprises more than 260 species of squat lobsters, distributed worldwide, and is one of the most diverse groups of deep-sea animals (Baba et al., 2008). Munidopsis species are adapted to a variety of abyssal habitats, such as seamounts, ocean plains, hydrothermal vents, cold seeps and whale falls. Whale falls or other types of large organic falls are unique ecosystems creating an island-type habitat that can sustain a specifically adapted benthic community, potentially enduring for decades (Smith et al., 1989; Baco \& Smith, 2003; Smith \& Baco, 2003; Ristova et al., 2017). The fauna in a carcass fall is often diverse and usually shows a high degree of endemism (Baco \& Smith, 2003; Smith \& Baco, 2003; Amon et al., 2013; Amon et al., 2017).

Known as opportunists, Munidopsis species have often been observed in whale-fall and wood-fall ecosystems (Williams, Smith \& Baco, 2000; Jones \& Macpherson, 2007; Macpherson, Amon \& Clark, 2014; Sumida et al., 2016; Amon et al., 2017). Previous studies found that Munidopsis species associated with whale falls or wood falls had a heterogeneous diet and could be scavengers, predators, bacterivorous detritivores and/or even wood-eaters, and were present in the community in every developmental stage (Janßen, Treude \& Witte, 2000; Smith \& Baco, 2003; Kemp et al., 2006; Macavoy et al., 2008; Hoyoux et al., 2012). Although Munidopsis species constitute an important part of organic-fall fauna, there has been little taxonomic study of the group in this ecosystem compared with other habitats (Jones \& Macpherson, 2007; Macpherson, Amon \& Clark, 2014).

To study the fauna and community characters of a deep-sea carcass-fall ecosystem, artificially placed carcass falls (cow bones) were deployed at Weijia Guyot in the western Pacific, in 2016 and 2018, by the Second Institute of Oceanography, Ministry of Natural Resources of the People's Republic of China. Two landers containing cow bones mimicking whale falls were placed on the seamount at a depth of 1,427 m and 3,225 m, respectively. Several specimens of Munidopsis were collected among the fauna, together with many amphipod scavengers. After 
69

careful examination, three specimens were identified as juveniles of $M$. albatrossae Pequegnat \& Pequegnat, 1973, a first record for this species in the West Pacific, and the other five specimens were found to be new to science. In addition to morphological analysis, we performed a barcoding analysis using sequences of the mtCOI gene to help the identification of specimens. Meanwhile, we selected a group of Munidopsis species morphologically similar to our specimens for phylogenetic analysis, most of which have mesial eyespines, relatively short P1 and triangular rostrum, and are generally associated with chemosynthetic environments (Baba \& de Saint Laurent, 1992; Jones \& Macpherson, 2007; Cubelio et al., 2016; Coykendall, Nizinski \& Morrison, 2017; Rodriguez-Flores, Macpherson \& Machordom, 2018). In present paper, we combined the morphological with molecular methods, in an attempt to clarify the systematic status of the present species from Weijia Guyot and assess their phylogenetic relationships with other congeners.

\section{Materials \& Methods}

\section{Sample collection and morphological examination}

Information on the Munidopsis species collected at Weijia Guyot and the molecular data used in the present study are listed in Table 1 . The carcass fall experiments were conducted using deep-sea landers including cow bones deployed on the seabed. The squat lobsters were collected when the landers were retrieved one year after the deployment. All specimens collected were found on the bones or within the lander boxes. After being photographed, the specimens were preserved in $80 \%$ ethanol. The size of the specimen is given as the postorbital carapace length (PCL), which refers to the carapace length excluding rostrum. All specimens collected in this study were deposited in the Sample Repository of Second Institute of Oceanography (SRSIO), Ministry of Natural Resources, Hangzhou, China. Field experiments were approved by the China Ocean Mineral Resources R \& D Association (Cruise 41 and 58).

Munidopsis lauensis Baba \& de Saint Laurent, 1992 was used as the comparative material for the phylogenetic analysis. The specimen was collected from a hydrothermal vent in Manus 
95

96

Basin, Bismarck Sea $\left(3^{\circ} 42.25^{\prime} \mathrm{S}, 151^{\circ} 52.66^{\prime} \mathrm{E}\right)$, at 1,714 m depth, in 19 June 2015.

Morphological and molecular data for specimens of M. nitida (A. Milne Edwards, 1880) used in the study were made available by Paula Rodriguez-Flores, Museo Nacional de Ciencias Naturales (MNCN-CSIC) and Centre d'Estudis Avançats de Blanes (CEAB-CSIC), Spain. Those specimens were collected off Papua New Guinea $\left(03^{\circ} 31^{\prime} \mathrm{S}, 148^{\circ} 03^{\prime} \mathrm{E}\right)$, at a depth range of 780 $855 \mathrm{~m}$, in 23 April 2014.

\section{Molecular data and analysis}

Total genomic DNA was extracted from muscle tissue using QIAamp DNA Mini Kit (QIAGEN, Hilden, Germany), following manufacturer instructions. Extracted DNA was eluted in double-distilled $\mathrm{H}_{2} \mathrm{O}\left(\mathrm{ddH}_{2} \mathrm{O}\right)$. Partial sequences of the $\mathrm{COI}$ gene were amplified via polymerase chain reaction (PCR). Reactions were carried out in a 30- $\mu$ l volume containing: $15 \mu \mathrm{l}$ Premix Taq (TaKaRa Taq ${ }^{\mathrm{TM}}$ Version 2.0 plus dye; TaKaRa, Kusatsu, Japan), $1.2 \mu \mathrm{l}$ each of forward and reverse primers $(10 \mathrm{mM})$, respectively, $1.6 \mu \mathrm{DNA}$ template, and $11 \mu \mathrm{ldd} \mathrm{d}_{2} \mathrm{O}$. For M. albatrossae, the primer pair gala_COIF and gala_COIR was used to amplify a fragment of 568 base pairs (bp) of the COI gene following the original procedure (Jones \& Macpherson, 2007). For M. spinifrons sp. nov. specimens, we designed a new reverse primer LCOgala (5'ATCATAAAGACATTGGAACTTTATA - 3') paired with the universal forward primer HCO2198 (Folmer et al., 1994) to obtain a fragment of ca. $660 \mathrm{bp}$ of the COI gene in the following thermal profile: initial denaturation at $95^{\circ} \mathrm{C}$ for $5 \mathrm{~min} ; 40$ cycles of $95^{\circ} \mathrm{C}$ for $50 \mathrm{~s} ; 49$ ${ }^{\circ} \mathrm{C}$ for $50 \mathrm{~s} ; 72{ }^{\circ} \mathrm{C}$ for $50 \mathrm{~s}$; and a final extension at $72{ }^{\circ} \mathrm{C}$ for $10 \mathrm{~min}$. We also amplified a fragment (672 bp) of the COI gene of M. lauensis for phylogenetic analysis using the universal primers HCO2198 and LCO1490 (Folmer et al., 1994) following the thermal profile described above. PCR products were purified using a QIAquick Gel Extraction Kit (QIAGEN, Hilden, Germany), and bidirectionally sequenced using the same primers with an ABI 3730xl Analyzer (Applied Biosystems, Foster City, CA, USA).

Sequences were checked by the sequence peak height and then assembled based on the 
122

123

124

125

126

127

128

129

130

131

132

133

134

135

136

137

138

139

140

141

142

143

144

145

146

147

148

contigs using the DNASTAR Lasergene software package (DNASTAR, Inc., Madison, WI, USA). The sequences acquired during this study were uploaded to NCBI GenBank (Table 1). We also downloaded several COI sequences of Munidopsidae species from GenBank (Table 1) for the phylogenetic analysis. Most of the chosen species, which are morphologically similar to either one of the two species presently studied, belong to the Orophorhynchus (A. MilneEdwards, 1880) group and associated with chemosynthetic environments (Ahyong, Andreakis \& Taylor, 2011). Two morphologically distinct species, M. barbarae (Boone, 1927) and $M$. corniculata Rodriguez-Flores, Macpherson \& Machordom, 2018, were chosen for comparative analysis, and Shinkaia crosnieri Baba \& Williams, 1998 was selected as the outgroup in the phylogenetic study.

The sequences were aligned using the software package MEGA 6.06 (Tamura et al., 2013).

The average genetic distances within and between species were estimated according to the Kimura 2-parameter (Kimura, 1980) model in MEGA 6.06 (Tamura et al. 2013). The most appropriate nucleotide base substitution model for the alignment data, which is $\mathrm{HKY}+\mathrm{I}+\mathrm{G}$, was determined by MrModeltest v2 (Nylander, 2004). The maximum likelihoods (ML) for phylogenetic analyses were assembled in PhyML 3.1 (Guindon \& Gascuel, 2003) with 1000 replicates. A Bayesian inference (BI) tree was constructed using MrBayes 3.2.6 (Huelsenbeck \& Ronquist, 2001). Markov chains were run for 10,000,000 generations, sampled every 100 generations; the first $25 \%$ trees were discarded as burn-in, after which remaining trees were used to construct the $50 \%$ majority-rule consensus tree and to estimate posterior probabilities.

\section{Zoobank registration}

The electronic version of this article in portable document format will represent a published work according to the International Commission on Zoological Nomenclature (ICZN), and hence the new names contained in the electronic version are effectively published under that Code from the electronic edition alone. This published work and the nomenclatural acts it contains have been registered in ZooBank, the online registration system for the ICZN. The ZooBank Life 
149 Science Identifiers (LSIDs) can be resolved and the associated information viewed through any 150 standard web browser by appending the LSID to the prefix http://zoobank.org/. The LSID for 151 this publication is: urn:lsid:zoobank.org:pub:C1CC52FD-6113-4A53-91C3-8D80E713D255.

152 The online version of this work is archived and available from the following digital repositories:

153 PeerJ, PubMed Central, and CLOCKSS.

154 Results

155

156

157

158

159

160

161

162

163

164

165

166

167

168

169

170

171

172

173

174

\section{Taxonomy}

Family Munidopsidae Ortmann, 1898

Genus Munidopsis Whiteaves, 1874

Munidopsis albatrossae Pequegnat \& Pequegnat, 1973

(Figs. 1, 2 and 3A)

Munidopsis sp. Wolff, 1961: 148, fig. 16.

Munidopsis albatrossae Pequegnat \& Pequegnat, 1973: 163, figs. 1, 2 (type locality: Eastern Pacific South of Madalena Bay, Baja California).-Baba, 2005: 284.—Jones \& Macpherson, 2007: 480, fig. 2A.—García Raso et al., 2008: 1282, fig. 2.

Munidopsis aries Ambler, 1980: 17.—Wicksten, 1989: 315 (not M. aries (A. Milne Edwards, 1880)).

Materials examined. SRSIO1709000X, 1 male (PCL $6.29 \mathrm{~mm}$ ), 1 female (PCL $6.51 \mathrm{~mm}$ ), $1 \mathrm{sex}$ indet. (PCL $4.02 \mathrm{~mm}$ ). Carcass fall experimental field site, Weijia Guyot, West Pacific. R/V Haiyang 6, stn. MCMX1605, 1243.0149’'N, 156²7.2057’'E, 3225 m, 30 September 2017.

Diagnosis. Carapace (Fig. 1A) (excluding rostrum) as long as broad. Frontal margins oblique, with blunt outer orbital angle above antennal peduncle. Anterolateral corners blunt, followed by notch at lateral end of anterior cervical groove and another low process; anterior branchial 
175

176

177

178

179

180

181

182

183

184

185

186

187

188

189

190

191

192

193

194

195

196

197

198

199

200

201

margins rugose, slightly convex, each with blunt anterior tooth; posterior branchial margins converging posteriorly. Dorsal surface with numerous rugae; gastric region elevated, with pair of low epigastric process. Rostrum broadly triangular, 1.3 times longer than broad, 0.6 length of remaining carapace; lateral margins straight, weakly serrated distally; dorsal surface and ventral surface (Fig. 1B) each with median, longitudinal ridge. Pterygostomial flaps (Fig. 1C) with oblique rugae on lateral surface; anteriorly acute. Sternal plastron (Fig. 1D) as long as broad; sternite 4 moderately elongated anteriorly, ventral surface depressed. Abdominal tergites unarmed; tergites 2 and 3 each with two transverse ridges on dorsal surface, anterior ridges more elevated. Telson (Fig. 1E) composed of 8 plates. Eyestalks short, unmovable, mesial eyespines present but reduced; cornea small. Basal article of antennular peduncle (Fig. 1B) with 2 anterior spines. Antennal peduncle (Fig. 1B) overreaching eyestalks. Merus of third maxilliped (Fig. 1F) armed with 3 or 4 small spines on flexor margin. Pereopod 1 (P1, chelipeds) (Fig. 2A) subequal; palms with rows of spines on lateral and mesial margins, dorsal surfaces with scattered spines; fingers with opposable margins distally spooned; fixed fingers with denticulate carina on distolateral margin. Pereopods 2-4 slender (P2-4) (Fig. 2B-E); meri spinulose on extensor and flexor margins; carpi each with 2 longitudinal, spinulose carinae on extensor surface; propodi each with 2 carinae on extensor surface and 1 pair of distal spines on flexor margin; dactyli (Fig. 2E) approximately 0.7 propodi length; flexor margin straight, with 7 elevated teeth, each bearing small corneous spines. P2 slightly overreaching distal end of P1. P1 with epipods.

Coloration. In preserved condition, grey white.

Distribution. East Pacific: south of Madalena Bay, Baja California, Costa Rica, East Pacific Rise, and Monterey Bay (California). Antarctic waters: Bellingshausen Sea. West Pacific: Weijia Guyot. Depth 1,920-3,680 m.

Habitats. The specimens described here were collected from cow bones in an artificial carcass fall, deployed at 3,225 $\mathrm{m}$ at Weijia Guyot. This species was previously found on a whale fall in Monterey Bay (Jone \& Macpherson, 2007), and on soft sea bottom in the Bellingshausen Sea (García Raso, García Muñoz \& Manjón-Cabeza, 2008). 
202

203

204

205

206

207

208

209

210

211

212

213

214

215

216

217

218

219

220

221

222

223

224

225

226

227

228

Remarks. The specimens from Weijia Guyot show a few differences from the holotype and the specimen from Monterey Bay. In the present specimens, the mesial eyespines are blunt and the anterior branchial margins are faintly serrated, whereas in the holotype, the mesial eyespines are prominent and the anterior branchial margins have numerous small spines (Pequegnat \& Pequegnat, 1973). The present specimens are all juveniles, with the PCL not longer than $7 \mathrm{~mm}$; in contrast, the specimens described from the East Pacific exceed $70 \mathrm{~mm}$ PCL. Therefore, the slight morphological differences can be considered intraspecific variations due to size.

\section{Munidopsis spinifrons sp. nov.}

urn:1sid:zoobank.org:act:B1A381D7-7BF1-4C37-A15F-33ACF009C833

(Figs. 3B, 4 and 5)

Munidopsis vrijenhoeki Jones \& Macpherson, 2007: 496 (part, small leg fragments?).

Materials examined. SRSIO18100001, holotype, 1 male (PCL 24.89 mm); SRSIO18100002, paratypes, 4 females (PCL 15.79-20.45 mm). Carcass fall experimental field site, Weijia Guyot, West Pacific. R/V Dayang 1, stn. DY48-II-MX1802, 1256.96’'N, 156 ${ }^{\circ} 57.25^{\prime} \mathrm{E}, 1427.5$ m, 25 October 2018.

Description. Carapace (Fig. 4A) (excluding rostrum) distinctly longer than broad. Frontal margins oblique, antennal spines well developed. Lateral margins approximately parallel, bearing short, sparse setae. Anterolateral spines relatively short. Anterior branchial margin with 3 or 4 spines; anteriormost spine strongest; posterior two spines usually rudimental. Posterior branchial margin rugose, with distinct spine at base of posterior cervical groove. Posterior margin unarmed, slightly concave. Dorsal surface covered with transverse, interrupted ridges, bearing long setae. Gastric region elevated, with 2 strong epigastric spines (followed with 2 tiny spines in holotype). Cervical groove distinct. Cardiac region with distnct transverse 
229

230

231

232

233

234

235

236

237

238

239

240

241

242

243

244

245

246

247

248

249

250

251

252

253

254

255

uninterrupted ridge. Rostrum spiniform (Fig. 4B), 0.4 times as long as remaining carapace length, 1.2 times broader than long (base at level of antennal spine base); dorsal surface evenly and longitudinally carinate; distal 0.3 length of lateral margins strongly upturned, bearing 1 or 2 small but distinct spines. Pterygostomial (Fig. 4C) flaps with oblique rugae on lateral surface.

Sternal plastron (Fig. 4D) slightly longer than broad, widening posteriorly. Sternite 3 broader than anterior margin of sternite 4, divided into two parts by median longitudinal groove; anterior margins with median notch. Sternite 4 narrowly elongated with longitudinal groove in anterior part; posterior part broad, surface with short scales, posterior surface depressed. Sternites 5-7 each with elevated, transverse ridges, bearing simple setae.

Abdominal tergites smooth and unarmed; tergites 2-4 each with 2 transverse ridges bearing stiff setae anteriorly, posterior ridge relatively short.

Telson (Fig. 4E) composed of 10 distinct plates.

Eyestalk (Fig. 4F) hardly movable. Cornea oval, globular, broader than long. Ocular peduncle short, nearly invisible in dorsal view, broader than cornea; mesial eyespine prominent, anterolaterally directed, reaching to distal 0.6 of rostrum; lateral eyespine relatively short, closely adjacent to cornea and followed with distinct spine on base of peduncle (usually covered by carapace in dorsal view).

Antennular peduncle (Fig. 4G, H) with basal article longer than broad; distal margin bearing strong ventrolateral spine and dorsolateral spine (rarely bearing another minute intermedian spine); lateral face slightly inflated, covered with short rugae; mesial margin straight.

Antennal peduncle (Fig. 4G) reaching to half length of rostrum, bearing setae on lateral and mesial margins. Article 1 immovable, with strong distomesial and distolateral spines. Article 2 armed with strong distolateral spine and small mesial spine at midlength. Article 3 subrectangular, with strong distomesial and distolateral spines, and minute dorsodistal spine. Article 4 short and unarmed.

Third maxilliped (Fig. 4I) slender. Ischium approximately as long as merus length, distoextensor corner acute; crista dentata well-developed, extending onto basis. Merus subrectangular, 
256

257

258

259

260

261

262

263

264

265

266

267

268

269

270

271

272

273

274

275

276

277

278

279

280

281

282

extensor margin with distinct distal spine followed by small tubercle; flexor margin irregularly denticulate. Carpus unnamed. Propodus with distoflexor margin convex. Dactylus short. Dactylus flexor margin, propodus distoflexor margin, and carpus dorsal distoflexor margin densely covered in long setae.

Pereopod 1 (P1, chelipeds) (Fig. 5A, B) subequal, 1.4 times PCL, densely covered in long and stiff setae on rugae and base of spines on surface and margins. Ischium short, approximately 0.7 merus length, distal margin with distinct dorsolateral spine and small ventrolateral spine; ventrodistal margin anteriorly produced, with strong subterminal spine. Merus approximately 0.4 PCL, subtriangular in cross-section, with short rugea on surfaces; dorsal surface armed with longitudinal row of spines (strongest on distal margin, successively decreasing in size); dorsodistal margin with another strong spine on mesial side; ventrodistal margin with strong mesial and lateral spines. Carpus less than half merus length, dorsomesial margin with strong subdistal spine and small median spine (disappearing on right P1 of holotype); dorsolateral margin with strong distal spine; ventrodistal margin produced into triangular lobe. Chela relatively compressed, approximately 1.3 merus length (including fixed finger), twice as longer as broad; palm unarmed. Fingers 0.8 palm length, opposable margins distally spooned and crenulated; occlusal margins sinuous, with low, triangular tooth proximally on fixed finger, and broad, low tooth medially on movable finger; distolateral margin of fixed finger with indistinct denticulate carina.

Pereopods 2-4 (P2-4, ambulatory legs 1-3) (Fig. 5C-F) setose, bearing long, stiff setae on margins and surfaces of each segment. P2 approximately 1.8 times PCL, overreaching distal end of cheliped. Meri somewhat compressed; P2 merus approximately 0.7 PCL (P3 merus 0.9 P2 merus length; P4 merus 0.8 P2 merus length), 4.3 times as long as broad (P3 3.8 times, P4 3.3 times); extensor margin armed with row of spines, distal-most spine prominent; flexor margin rugose, with strong distal spine. Carpi each with 2 longitudinal ridges on extensor surface; lateral carina rugose, armed with small distal spine (P2, sometimes absent) or unarmed (P3 and P4); mesial carina armed with row of 3-6 spines, distal spine laterally situated and subequal (or 
283

284

285

286

287

smaller) in size to penultimate spine; flexor margin armed with small but acute distal spine. Propodi subcylindrical, $\mathrm{P} 2$ propodus 0.8 merus length ( $\mathrm{P} 2-4$ propodi subequal in length); extensor surface nearly flat, with 2 longitudinal carinae; flexor margin rugose, with pair of distal corneous spines. Dactyli (Fig. 5F) 0.4-0.5 propodi length; extensor margin rugose; flexor margin straight, with 11 movable corneous spines (increasing in size distally) each based on triangular tooth.

P1 with epipod.

Distribution. Known only from the type locality, Weijia Guyot, West Pacific; $1427.5 \mathrm{~m}$.

Coloration. In fresh condition, body entirely white, cornea light orange.

Habitats. The species is currently recorded only from the artificially placed deep-sea carcass fall (cow bones) at Weijia Guyot, western Pacific.

Etymology. Latin words "spini-" means spinose or spiny, and "frons" means the rostrum. The new specific name refers to the special character that discriminates it from the closely related species.

Remarks. The new species is morphologically similar to M. nitida in having a narrow rostrum, parallel carapace lateral margins, pair of strong epigastric spines, mesial and lateral eyespines, broad cornea, unarmed abdominal segments, anterior branchial margin with 2-4 spines, P1 shorter than P2, and epipod present on P1. Munidopsis spinifrons sp. nov. can be readily distinguished from M. nitida in having small distal spines on the lateral margins of the rostrum, and a basal lateral eyespine; in M. nitida, the lateral margins of the rostrum are entire (Baba, 2005 ) and the eyestalk bears only a distal lateral eyespine. The latter character has not been mentioned in previous literature, but according to the illustration in Baba (2005: Fig. 72e), $M$. nitida lacks such a basal lateral eyespine. This was also supported by examination of specimens from New Guinea (Paula Rodríguez Flores, pers. comm.). The character of the spinose rostrum can be observed on all five of the present specimens, regardless of the size and sex, although the spines are weak on the smallest specimen; therefore we accept it as a consistent and reliable interspecific character. The new species resembles M. exuta Macpherson \& Segonzac, 2005 in 
310 having a narrow rostrum with small lateral marginal spines and a pair of strong epigastric spines.

311 Munidopsis spinifrons sp. nov. differs from M. exuta in having antennal spines, 10 telson plates,

312 lateral eyespines, and denticulate carina on the P1 fixed finger.

313 COI sequence data (see below) show that the new species is closely related to M. vrijenhoeki.

314 However, those two species differ morphologically. Besides the spinose rostrum, the new species

315 has a narrow rostrum, pair of strong epigastric spines, 10 telson plates, large cornea, anterior

316 branchial margins with 2 or 3 spines, 3rd maxillipeds meri with irregular denticles on the flexor

317 margins, P1 with epipods, and P2-4 meri each with a row of spines only on the extensor margin.

318 In contrast, $M$. vrijenhoeki has a broad rostrum, pair of small epigastric spines, 8 telson plates,

319 small cornea, branchial margins nearly unarmed, 3rd maxillipeds meri with well-developed

320 spines on the flexor margin, P1 without epipod, and P2-4 meri with a row of spines on the flexor

321

322

323

324

325

326

327

328

329

330

331

332

333

334

335

336 margin. The genetic relationships are discussed in the Discussion section.

\section{Molecular data analysis}

Kimura's two-parameter pairwise genetic distances between $M$. albatrossae from the Weijia Guyot and a specimen from the Monterey Bay (Jones \& Macpherson, 2007) was 0.4\%, suggesting that the specimens are the same species. The genetic distances between M. aries from the northeastern Atlantic (Jones \& Macpherson, 2007) and M. albatrossae from both the Weijia Guyot and Monterey Bay were $1.8 \%$ and $1.4 \%$, respectively, indicating a close relationship between these two species.

Kimura's two-parameter pairwise genetic distance between $M$. spinifrons sp. nov. and $M$. nitida was 4\%, indicating clear genetic divergence. However, M. spinifrons sp. nov., including all five sequences, showed no significant genetic distance compared with M. vrijenhoeki Mvri2 (DQ677675), yet displayed high genetic distance compared with M. vrijenhoeki Mvri3 (DQ677676), at 1.7\%.

The combined phylogenetic trees (Fig. 6) reconstructed from both the ML and BI analyses are generally congruent. In the combined trees, $M$. albatrossae from both the west and east 
337 Pacific cluster together (BP [maximum likelihood bootstrap percentage] =91), although the

338

339

340

341

342

343

344

345

346

347

348

349

350

351

352

353

354

355

356

357

358

359

360

361

362 Bayesian posterior probability (PP) are modest. Meanwhile, M. albatrossae and M. aries form a highly supported monophyletic clade $\mathrm{A}(\mathrm{BP}=100, \mathrm{PP}=1.00)$ suggesting the close relationship of these two species.

In the phylogenetic tree (Fig. 6), M. spinifrons sp. nov., M. vrijenhoeki (both Mvri2 and Mvri3), and $M$. nitida form highly supported clade B $(\mathrm{BP}=94, \mathrm{PP}=1.00)$, indicating their close relationship. The five specimens of the new species cluster together into a subclade, although the bootstrap value is modest $(\mathrm{BP}=65)$; nevertheless, $M$. vrijenhoeki Mvri3 and $M$. nitida form a strongly supported subclade $(\mathrm{BP}=98, \mathrm{PP}=1.00)$, illustrating that they are more genetically related than the rest of the species (individuals) within clade B. Munidopsis lauensis and M. myojinensis Cubelio, Tsuchida, Hendrickx, Kado \& Watanabe, 2007, together with clade B, compose a large clade $\mathrm{C}$ with high Bayesian support $(\mathrm{PP}=0.99)$.

\section{Discussion}

The COI gene is considered much conserved in the genus Munidopsis, following studies between populations and among sibling species (Jones \& Macpherson, 2007; Thaler et al., 2014; Coykendall, Nizinski \&Morrison, 2017). The smallest nucleotide divergences for mtCOI between species of Munidopsis from the EP Rise are 1.6\%-1.9\% (Jones \& Macpherson, 2007). The genetic distance (Kimura's two-parameter pairwise), however, observed between $M$. albatrossae (from Monterey Bay) and M. aries (northeastern Atlantic) was $1.4 \%$, which is smaller than that reported by Jones and Machpherson (2007) (2.8\%), probably because data from different specimens were used. Similarly, M. albatrossae from the Weijia Guyot displayed very low genetic distance compared with specimens from the East Pacific, although their geographic distance is vast. Harino et al. (2005) mentioned the capture of M. albatrossae at the Nankai Through, off the south coast of Japan, but that record was not confirmed by taxonomic examination. Therefore, the current report is considered the first definite record of $M$. albatrossae distributed in the West Pacific. García Raso, García Muñoz \& Manjón-Cabeza (2008) 
363

364

365

366

367

368

369

370

371

372

373

374

375

376

377

378

379

380

381

382

383

384

385

386

387

388

389

also reported the occurrence of this species in Antarctic waters (west of Peter I Island). Together, these findings suggest that M. albatrossae has a wide distribution range in the Pacific Ocean. Among the sampling localities reported in the present and previous studies, the Weijia Guyot and Monterey Bay are the only two places where the specimens were observed in a whale-fall or carcass-fall environment.

The type material of $M$. vrijenhoeki comprised of three specimens: the holotype and the small leg fragments of two other specimens (Jones \& Macpherson, 2007); three COI sequences were published in GenBank based on these materials (DQ677674-DQ677676, representing Mvri1Mvri3). The sequence of DQ677674 (Mvri1) was assigned to the holotype, but annotated as including two individuals. However, as compared with other molecular data, the Mvril sequence was too short (211 bp, identical with part of Mvri2) to be used for phylogenetic analysis in the present study. The genetic distance observed between M. spinifrons sp. nov. and Mvri2 specimen was 0 , but was significantly higher (1.7\%) between M. spinifrons sp. nov. and Mvri3. Moreover, the combined phylogenetic tree confirms that Mvri3 is more closely related to M. nitida than to Mvri2 and M. spinifrons sp. nov., with high support. These results suggest that the type material of M. vrijenhoeki represents at least 2 valid species. Consequently, we think that one or two of the leg fragments attributed to M. vrijenhoeki might instead belong to the present new species, and that the Mvri3 sequence might be derived from the holotype. Still, the morphological differences were sufficiently distinct to distinguish our specimens as representing a valid species separate from $M$. vrijenhoeki. Nonetheless, additional samples accompanied by molecular examination involving multi-genes are needed to verify their actual systematic relationship.

The phylogenetic relationships among species within Munidopsis genus has been fully discussed (Jones \& Macpherson, 2009; Ahyong, Andreakis \& Taylor, 2011; Coykendall, Nizinski \& Morrison, 2017). According to the phylogenetic tree in the present study (Fig. 6), the species (or specimens) from the West Pacific (except M. albatrossae in Weijia Guyot) are all clustered together in clade C, while species from the East Pacific and Atlantic are scattered in other clades, suggesting a level of genetic divergence between fauna from different geographic 
390

391

392

393

394

395

396

397

398

399

400

401

402

403

404

405

406

407

408

409

410

411

412

413

414

415

regions. However, some West-Pacific species (or specimens) are morphologically more similar to congeners from the East Pacific and Atlantic Ocean. For example, M. spinifrons and M. nitida from the West Pacific resemble the East-Pacific species, M. bracteosa Jones \& Macpherson, 2009 and M. scotti Jones \& Macpherson, 2009, in having strong spines on the anterior branchial margins; on the contrary, M. lauensis and M. vrijenhoeki from the West Pacific lack such spines. The broad rostrum and small cornea also link M. vrijenhoeki to M. aries and M. bermudezi Chace, 1939 in Atlantic Ocean. The current result supports the idea that there is no correlation between morphological and genetic divergences (at least based on COI) for squat lobsters (Jones $\&$ Macpherson, 2009). Since the COI gene of Munidopsis species is much conserved and indirectly correlated to the morphological differentiations, more barcoding genes are needed to be explored for the species identity, and multi-genes conjoint analysis is necessary to reveal the phylogenetic relationship among species from different geographic areas.

Juveniles of squat lobsters have seldom been described, either from a natural or artificial carcass fall or wood fall. The M. albatrossae collected from Weijia Guyot were all juveniles, with the longest being only $6.51 \mathrm{~mm}$ PCL; in contrast, specimens of this species from other localities reach 87 mm PCL (Pequegnat \& Pequegnat, 1973). Jones and Macpherson (2007) also examined a juvenile collected from a whale fall. Hoyoux et al. (2012) found adults of a

Munidopsis species within mesh boxes (containing woody baits), with body sizes larger than the mesh size, meaning that the species would have entered the boxes as larvae. The available evidence supports the view that large organic falls may attract Munidopsis larvae by acting as a nursery area, but where their growth into other life stages may be sustained. Carcass falls are considered as "stepping stones" for species endemic in chemosynthetic environment to disperse over large distances (Smith et al., 1989; Distel et al., 2000; Smith \& Baco, 2003; Amon et al., 2013). Accordingly, this unique habitat would function likewise for squat lobsters, which are widespread and opportunistic in this ecosystem. 
416

417

418

419

420

421

422

423

424

425

426

427

428

429

430

431

432

433

434

435

436

437

438

\section{Conclusion}

The new species M. spinifrons sp. nov. was established based on morphological and molecular studies. It is morphologically different with the closely related species in having spinose rostrum and basal lateral eyespine on the eyestalk. The new species had a very low COI genetic distance with M. vrijenhoeki, but further molecular analysis showed that the type material of M. vrijenhoeki contained at least 2 valid species, one of which might belong to the present new species. More sampling effort and multi-gene analysis are needed in the future to verify their actual systematic relationship. The discovery of juvenile individuals of $M$.

albatrossae in this study supports the view that large organic falls in the deep sea may act as nursery area in some squat lobsters' life history, which is crucial for their dispersal over large distances.

\section{Acknowledgement}

We are extremely grateful to Dr Paula Carolina Rodriguez-Flores and Prof. Enrique Macpherson for providing us with valuable morphological and molecular data on M. nitida. We extend sincere thanks to associate professor Dongsheng Zhang for help with the sample collection.

\section{References}

Ambler JW. 1980. Species of Munidopsis (Crustacea, Galatheidae) occurring off Oregon and in adjacent waters. Fishery Bulletin 78:13-34.

Amon DJ, Glover AG, Wiklund H, Marsh L, Linse K, Rogers AD, Copley JT. 2013. The discovery of a natural whale fall in the Antarctic deep sea. Deep-Sea Research II 92:87-96. Amona DJ, Copley JT, Dahlgren TG, Horton T, Kemp KM, Rogers AD, Glover AG. 2017. Observations of fauna attending wood and bone deployments from two seamounts on the 
439

440

441

442

443

444

445

446

447

448

449

450

451

452

453

454

455

456

457

458

459

460

461

462

463

464

465

Southwest Indian Ridge. Deep-Sea Research II 136:122-132

Ahyong ST, Andreakis N, Taylor J. 2011. Mitochondrial phylogeny of the deep-sea squat lobsters, Munidopsidae (Galatheoidea). Zoologischer Anzeiger 250:367-377.

Baba K. 2005. Deep-sea chirostylid and galatheid crustaceans (Decapoda: Anomura) from the Indo-West Pacific, with a list of species. Galathea Reports 20:1-317.

Baba K, de Saint Laurent M. 1992. Chirostylid and galatheid crustaceans (Decapoda: Anomura) from active thermal vent areas in the southwest Pacific. Scientia Marina 56:321-332.

Baba K, Macpherson E, Poore GCB, Ahyong ST, Bermudez A, Cabezas P, Lin CW, Nizinski M, Rodrigues C, Schnabel KE. 2008. Catalogue of squat lobsters of the world (Crustacea: Decapoda: Anomura families Chirostylidae, Galatheidae and Kiwaidae). Zootaxa 1905:1220 .

Baba K, Williams AB. 1998. New Galatheoidea (Crustacea, Decapoda, Anomura) from hydrothermal systems in the West Pacific Ocean: Bismarck Archipelago and Okinawa Trough. Zoosystema 20:143-156.

Baco AR, Smith CR. 2003. High species richness in deep-sea chemoautotrophic whale skeleton communities. Marine Ecology Progress Series 260:109-114.

Boone L. 1927. Scientific results of the first oceanographic expedition of the "Pawnee", 1925. Crustacea from the tropical east American Seas. Bulletin of the Bingham Oceanographic Collection 1:1-147.

Chace FA. 1939. Reports on the scientific results of the first Atlantis Expedition to the West Indies, etc. Preliminary descriptions of one new genus and seventeen new species of decapod and stomatopod Crustacea. Memorias de la Sociedad Cubana de Historia Natural 13:31-54.

Coykendall DK, Nizinski MS, Morrison CL. 2017. A phylogenetic perspective on diversity of Galatheoidea (Munida, Munidopsis) from cold-water coral and cold seep communities in the western North Atlantic Ocean. Deep-Sea Research II 137:258-272.

Cubelio SS, Tsuchida S, Hendrickx ME, Kado R, Watanabe S. 2007. A new species of vent associated Munidopsis (Crustacea: Decapoda: Anomura: Galatheidae) from the Western 
466

467

468

Pacific, with notes on its genetic identification. Zootaxa 1435:25-36.

Folmer O, Black M, Hoeh W, Lutz R, Vrijenhoek R. 1994. DNA primers for amplification of mitochondrial cytochrome $\mathrm{C}$ oxidase subunit I from diverse metazoan invertebrates. Molecular Marine Biology and Biotechnology 3:294-299.

García Raso JE, García Muñoz JE, Manjón-Cabeza ME. 2008. First record of Munidopsis albatrossae (Crustacea: Decapoda: Galatheidae) from Antarctic waters. Polar Biology $31: 1281-1285$.

Goffredi SK, Johnson S, Tunnicliffe V, Caress D, Clague D, Escobar E, Lundsten L, Paduan JB, Rouse G, Salcedo DL, Soto LA, Spelz-Madero R, Zierenberg R, Vrijenhoek R. 2017. Hydrothermal vent fields discovered in the southern Gulf of California clarify role of habitat in augmenting regional diversity. Proceedings of the Royal Society B 284:20170817.

Guindon S, Gascuel O. 2003. A simple, fast, and accurate algorithm to estimate large phylogenies by maximum likelihood. Systematic Biology 52:696-704.

Harino H, Iwasaki N, Arai T, Ohji M, Miyazaki N. 2005. Accumulation of organotin compounds in the deep-sea environment of Nankai Trough, Japan. Archives of Environmental Contamination and Toxicology 49(4):497-503

Hoyoux C, Zbinden M, Samadi S, Gaill F, Compère P. 2012. Diet and gut microorganisms of Munidopsis squat lobsters associated with natural woods and mesh-enclosed substrates in the deep South Pacific. Marine Biology Research 8:28-47.

Huelsenbeck JP, Ronquist F. 2001. MRBAYES: Bayesian inference of phylogeny. Biometrics 17:754-755.

Janßen F, Treude T, Witte U. 2000. Scavenger assemblages under differing trophic conditions: A case study in the deep Arabian Sea. Deep Sea Research II 47:2999-3026.

Jones WJ, Macpherson E. 2007. Molecular phylogeny of the East Pacific squat lobsters of the genus Munidopsis (Decapoda: Galatheidae) with the descriptions of seven new species. Journal of Crustacean Biology 27:477-501.

Kemp KM, Jamieson AJ, Bagley PM, McGrath H, Bailey DM, Collins MA, Priede IG. 2006. 
493

494

495

496

497

498

499

Consumption of large bathyal food fall, a six month study in the NE Atlantic. Marine Ecology Progress Series 310:65-76.

Kimura M. 1980. A simple method for estimating evolutionary rates of base substitutions through comparative studies of nucleotide sequences. Journal of Molecular Evolution $16: 111-120$.

Macavoy SE, Carney RS, Morgan E, Macko SA. 2008. Stable isotope variation among the mussels Bathymodiolus childressi and associated heterotrophic fauna at four cold-seeps communities in the Gulf of Mexico. Journal of Shellfish Research 27:147-51.

Macpherson E, Segonzac M. 2005. Species of the genus Munidopsis (Crustacea, Decapoda, Galatheidae) from the deep Atlantic Ocean, including cold-seep and hydrothermal vent areas. Zootaxa 1095:1-60.

Macpherson E, Amon D, Clark PF. 2014. A new species of Munidopsis from a seamount of the Southwest Indian Ocean Ridge (Decapoda: Munidopsidae). Zootaxa 3753: 291-296

Milne Edwards A. 1880. Reports on the results of dredging under the supervision of Alexander Agassiz, in the Gulf of Mexico and in the Caribbean Sea, etc. VIII. Etudes preliminaires surles Crustacés. Bulletin of the Museum of Comparative Zoology at Harvard College 8:1-68. Nylander JAA. 2004. MrModeltest v 2. Program distributed by the author. Evolutionary Biology Centre, Uppsala University, Uppsala, Sweden.

Ortmann AE. 1898. Crustacea, Malacostraca. In: Gerstäcker A, Ortmann AE eds. Die Klassen und Ordnungen der Arthropoden wissenschaftlich dargestellt in Wort und Bild, in H.G. Bronn's Die Klassen und Ordnungen der Thier-Reichs wissenschaftlich dargestellt in Wort und Bild. Leipzig: Winter'sche Verlagshandlung, 5 (2):1057-1168.

Pequegnat WE, Pequegnat LH. 1973. Munidopsis albatrossae, a new species of deep-sea Galatheidae (Decapoda, Anomura) from the Eastern Pacific Ocean. Crustaceana 24:163-168. Pop Ristova P, Bienhold C, Wenzhöfer F, Rossel PE, Boetius A. 2017. Temporal and Spatial Variations of Bacterial and Faunal Communities Associated with Deep-Sea Wood Falls. PLoS ONE 12(1): e0169906. DOI:10.1371/journal. pone.0169906 
Rodríguez-Flores PC, Macpherson E, Machordom A. 2018. Three new species of squat lobsters of the genus Munidopsis Whiteaves, 1874, from Guadeloupe Island, Caribbean Sea (Crustacea, Decapoda, Munidopsidae). Zootaxa 4422(4):569-580.

Shen Y, Kou Q, Chen W, He S, Yang M, Li X, Gan X. 2016. Comparative population structure of two dominant species, Shinkaia crosnieri (Munidopsidae: Shinkaia) and Bathymodiolus platifrons (Mytilidae: Bathymodiolus), inhabiting both deep-sea vent and cold seep inferred from mitochondrial multi-genes. Ecology and Evolution 6 (11):3571-3582.

Smith CR, Baco AR. 2003. Ecology of whale falls at the deep-sea floor. Oceanography and Marine Biology 41:311-354.

Smith CR, Kukert H, Wheatcroft RA, Jumars PA, Deming JW. 1989. Vent fauna on whale remains. Nature 34:27-128.

Sumida PYG, Alfaro-Lucas JM, Shimabukuro M, Kitazato H, Perez JAA, Soares-Gomes A, Toyofuku T, Lima AOS, Ara K, Fujiwara Y. 2016. Deep-sea whale fall fauna from the Atlantic resembles that of the Pacific Ocean. Scientific Reports 6: 22139. DOI: $10.1038 /$ srep22139.

Tamura K, Stecher G, Peterson D, Filipski A, Kumar S. 2013. MEGA6: molecular evolutionary genetics analysis version 6.0. Molecular Biology and Evolution 30:2725-2729.

Thaler AD, Plouviez S, Saleu W, Alei F, Jacobson A, Boyle EA, Schultz TF, Carlsson J, Van Dover CL. 2014. Comparative population structure of two deep-sea hydrothermal-ventassociated Decapods (Chorocaris sp. 2 and Munidopsis lauensis) from Southwestern Pacific Back-Arc Basins. PLoS ONE 9(7):e101345. DOI:10.1371/journal.pone.0101345.

Whiteaves JF. 1874. On recent deep-sea dredging operations in the Gulf of St. Lawrence. American Journal of Science (ser. 3) 7:210-219.

Wicksten MK. 1989. Ranges of offshore decapod crustaceans in the eastern Pacific Ocean. Transactions of the San Diego Society of Natural History 21:291-316.

Williams AB, Smith CR, Baco AR. 2000. New species of Paralomis (Decapoda, Anomura, Lithodidae) from a sunken whale carcass in the San Clemente basin off southern California. 
547 Journal of Crustacean Biology 20 (special number 2):281-85.

548 Wolff T. 1961. Animal life from a single abyssal trawling. Galathea Reports 5:129-162. 
550 Figure 1 Munidopsis albatrossae Pequegnat \& Pequegnat, 1973. SRSIO1709000X, male. (A) 551 carapace and abdominal tergites 1-3, dorsal view; (B) rostrum, eye, left antennule and antenna, 552 ventral view; (C) carapace and right pterygostomian, lateral view; (D) sternal plastron, ventral 553 view; (E) telson, dorsal view; (F) left third maxilliped and ischium crista dentata, ventral view. 554 Scales equal $1.0 \mathrm{~mm}$.

555

556 Figure 2 Munidopsis albatrossae Pequegnat \& Pequegnat, 1973. SRSIO1709000X, male. (A)

557 left cheliped (P1), dorsal view; (B) left pereopod 2 (P2, with setae), lateral view; (C) left

558

559

560

561

562

563

564

565

566

567

568

569

570

571

572

573

574

575

576

pereopod 3 (P3), lateral view; (D) left pereopod 4 (P4), lateral view; (E) dactylus of left P2, lateral view. Scales equal $1.0 \mathrm{~mm}$.

Figure 3 Photos of specimens examined, preserved in ethanol. (A) Munidopsis albatrossae Pequegnat \& Pequegnat, 1973, SRSIO1709000X, male; (B) Munidopsis spinifrons sp. nov., SRSIO18100001, holotype.

Figure 4 Munidopsis spinifrons sp. nov., SRSIO18100001, holotype. (A) carapace and abdominal tergites 1-3, dorsal view; (B) distal part of rostrum, dorsal view; (C) carapace and left pterygostomian, lateral view; (D) sternal plastron, ventral view; (E) telson, dorsal view; (F) left eyestalk, dorsal view; $(\mathrm{G})$ left antennule and antenna, ventral view; $(\mathrm{H})$ right antennule, ventral view; (I) left third maxilliped and ischium crista dentata, ventral view. Scales equal $1.0 \mathrm{~mm}$.

Figure 5 Munidopsis spinifrons sp. nov. SRSIO18100001, holotype. (A) right cheliped (P1), dorsal view (setae only shown on lateral margin of merus); (B) right cheliped (P1), ventral view; (C) right pereopod 2 (P2, with setae), lateral view; (D) right pereopod 3 (P3), lateral view; (E) right pereopod 4 (P4), lateral view; (F) dactylus of right P2, lateral view. Scales equal $1.0 \mathrm{~mm}$.

Figure 6 Phylogenetic tree obtained by the Maximum likelihood analysis based on the COI gene 
577 sequences. Maximum likelihood bootstrap scores (BP, above) and Bayesian posterior

578 probabilities (PP, below or right) are indicated adjacent to each node. Values of $\mathrm{BP} \geq 75 \%$ and

$579 \mathrm{PP} \geq 0.95$ are marked red. Only values of $\mathrm{BP} \geq 50 \%$ and $\mathrm{PP} \geq 0.5$ are shown. 


\section{Table $\mathbf{1}$ (on next page)}

Species, vouchers ID, Genbank accession numbers and references in this study. 
1 Table 1. Species, vouchers ID, Genbank accession numbers and references in this study.

\begin{tabular}{|c|c|c|c|}
\hline Species & Vouchers/sample codes & $\begin{array}{l}\text { GenBank accession } \\
\text { numbers }\end{array}$ & References \\
\hline Munidopsis spinifrons sp. nov. & SRSIO18100001 & MN397915 & Present study, holotype \\
\hline Munidopsis spinifrons sp. nov. & SRSIO18100002 & MN397916 & Present study, paratype \\
\hline Munidopsis spinifrons sp. nov. & SRSIO18100002 & MN397917 & Present study, paratype \\
\hline Munidopsis spinifrons sp. nov. & SRSIO18100002 & MN397918 & Present study, paratype \\
\hline Munidopsis spinifrons sp. nov. & SRSIO18100002 & MN397919 & Present study, paratype \\
\hline Munidopsis albatrossae & SRSIO1709000X & MN397920 & Present study \\
\hline Munidopsis lauensis & M159_19 & MN397921 & Present study \\
\hline Munidopsis nitida & M202 & MN397922 & Present study \\
\hline Munidopsis nitida & M203 & MN397923 & Present study \\
\hline Munidopsis albatrossae & USNM 1101472 & DQ677692 & Jones \& Macpherson, 2007 \\
\hline Munidopsis antonii & & DQ677686 & Jones \& Macpherson, 2007 \\
\hline Munidopsis aries & & DQ677691 & Jones \& Macpherson, 2007 \\
\hline Munidopsis barbarae & MNHN-IU-2014-13822 & MG979479 & $\begin{array}{l}\text { Rodriguez-Flores, } \\
\text { Macpherson } \\
\text { Machordom, } 2018\end{array}$ \\
\hline Munidopsis bermudezi & J2282_01 & KX016541 & $\begin{array}{l}\text { Coykendall, Nizinski \& } \\
\text { Morrison, } 2017\end{array}$ \\
\hline Munidopsis bracteosa & & DQ677684 & Jones \& Macpherson, 2007 \\
\hline Munidopsis cascadia & USNM 1100637 & DQ677694 & Jones \& Macpherson, 2007 \\
\hline Munidopsis corniculata & MNHN-IU-2013-19128 & MG979481 & $\begin{array}{l}\text { Rodriguez-Flores, } \\
\text { Macpherson } \\
\text { Machordom, } 2018\end{array}$ \\
\hline Munidopsis exuta & & DQ677690 & Jones \& Macpherson, 2007 \\
\hline Munidopsis kensmithi & SIO C10973 & DQ677709 & Jones \& Macpherson, 2007 \\
\hline
\end{tabular}




\begin{tabular}{|l|l|l|l|}
\hline Munidopsis livida & J2282-02 & KX016546 & Coykendall, Nizinski \& \\
\hline Munidopsis myojinensis & NSMT-Cr16877 & EF143603 & Morrison, 2017 \\
\hline Munidopsis recta & SIO C10969 & DQ677702 & Cubelio et al., 2016 \\
\hline Munidopsis scotti & D751_5 & KY581548 & Jones \& Macpherson, 2007 \\
\hline Munidopsis similis & 4179_01 & KX016549 & Goffredi et al., 2017 \\
\hline Munidopsis verrucosus & SIO C10881 & & Coykendall, Nizinski \& \\
\hline Munidopsis vrijenhoeki & & DQ677710 & Morrison, 2017 \\
\hline Munidopsis vrijenhoeki & & DQ677676 & Jones \& Macpherson, 2007 \\
\hline Shinkaia crosnieri & & KQ677675 & Jones \& Macpherson, 2007 \\
\hline
\end{tabular}

2 


\section{Figure 1}

1st line drawing of Munidopsis albatrossae

Munidopsis albatrossae Pequegnat \& Pequegnat, 1973. SRSIO1709000X, male. (A) carapace and abdominal tergites 1-3, dorsal view; (B) rostrum, left antennule and antenna, ventral view; (C) right pterygostomian, lateral view; (D) sternal plastron, ventral view; $(E)$ telson, dorsal view; $(F)$ left third maxilliped and ischium crista dentata, ventral view. Scales equal 1.0 $\mathrm{mm}$.

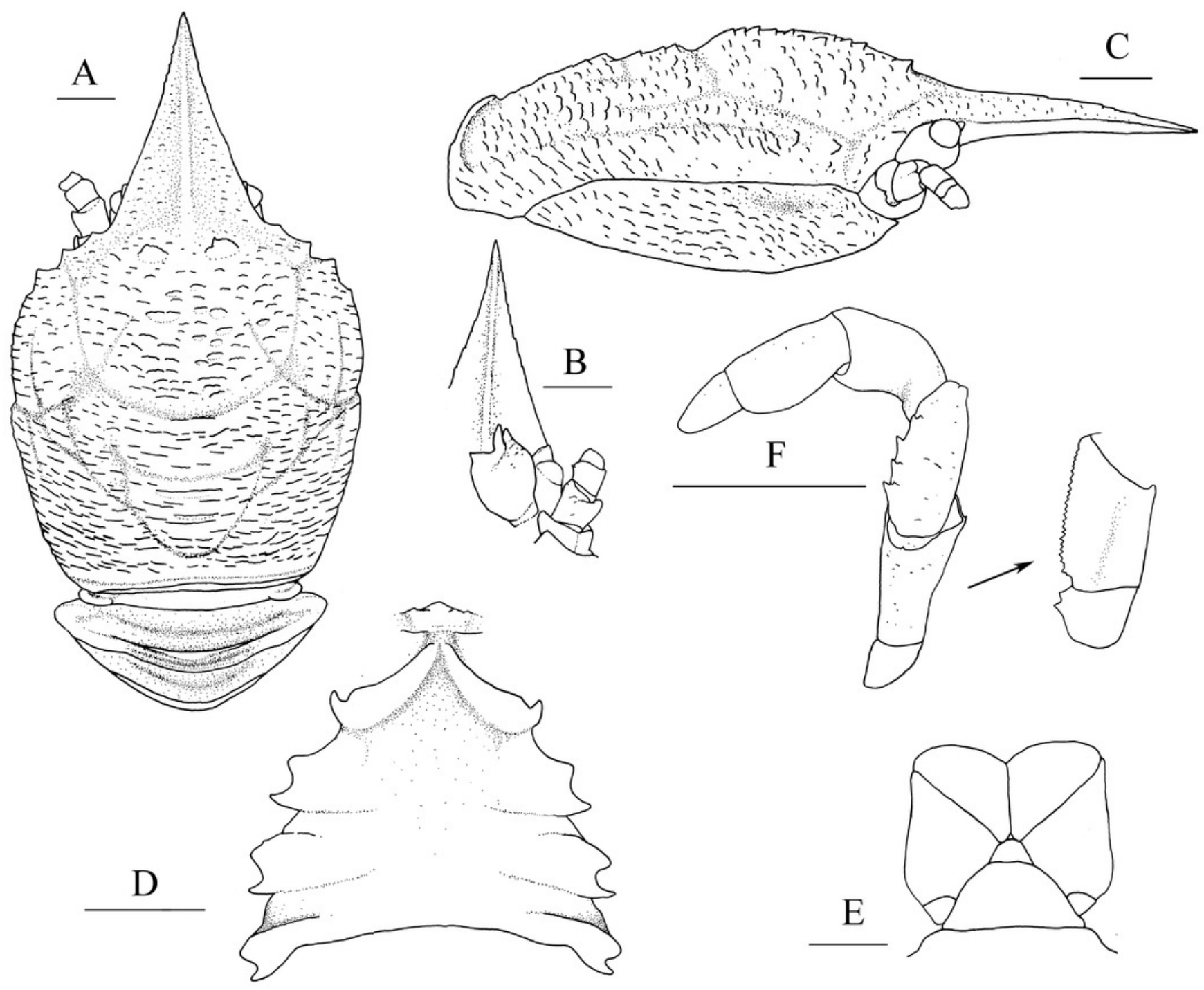




\section{Figure 2}

2nd line drawing of Munidopsis albatrossae

Munidopsis albatrossae Pequegnat \& Pequegnat, 1973. SRSIO1709000X, male. (A) left cheliped (P1), dorsal view (setae omitted); (B) left pereopod 2 (P2), lateral view; (C) left pereopod 3 (P3), lateral view (setae omitted); (D) left pereopod 4 (P4), lateral view (setae omitted); (E) dactylus of left P2, lateral view (setae omitted). Scales equal $1.0 \mathrm{~mm}$.

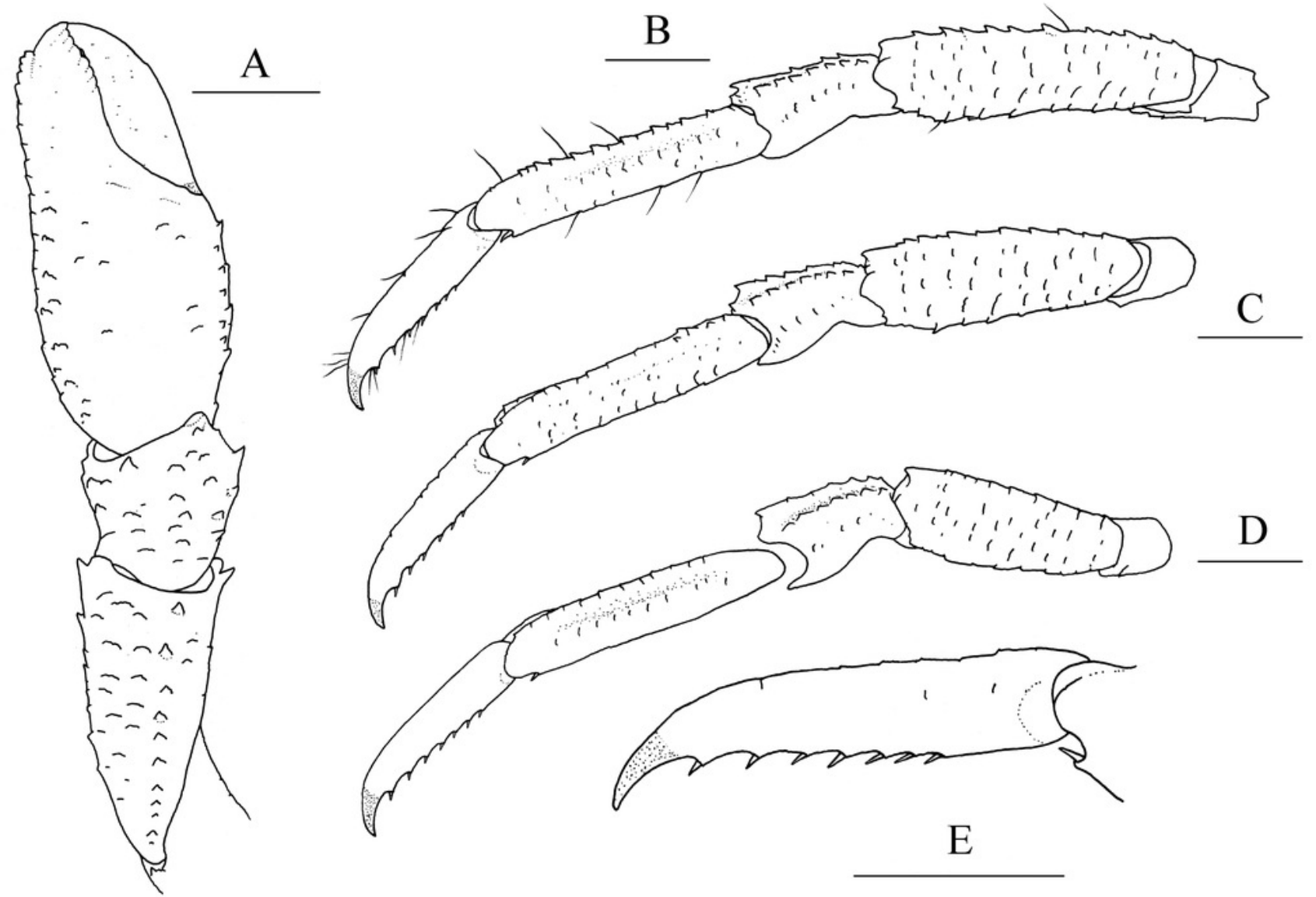




\section{Figure 3}

Photos of specimens examined, preserved in ethanol

Photos of specimens examined, preserved in ethanol. (A) Munidopsis albatrossae Pequegnat \& Pequegnat, 1973, SRSI01709000X, male; (B) Munidopsis spinifrons sp. nov., SRSIO18100001, holotype.

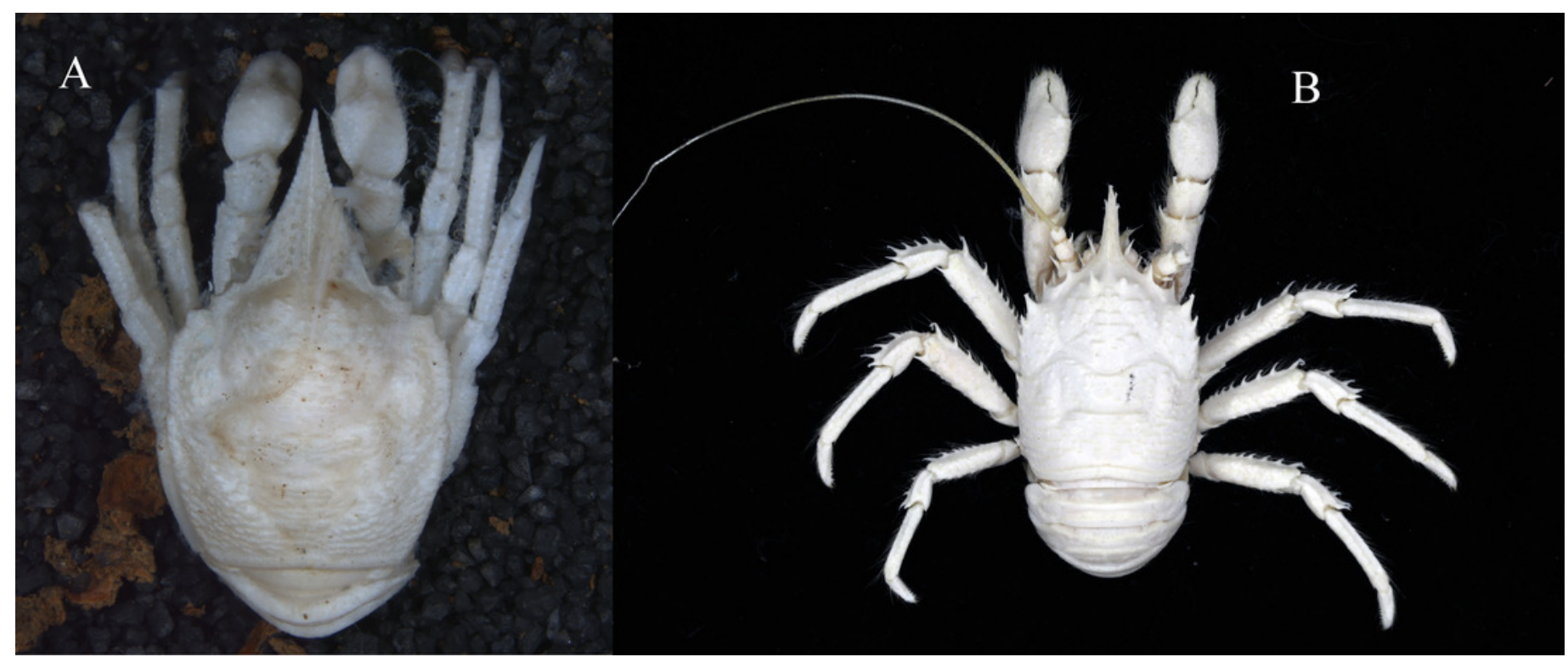




\section{Figure 4}

1st line drawing of Munidopsis spinifrons

Munidopsis spinifrons sp. nov., SRSIO18100001, holotype. (A) carapace and abdominal tergites 1-3, dorsal view; (B) distal part of rostrum, dorsal view; (C) carapace and left pterygostomian, lateral view; (D) sternal plastron, ventral view; (E) telson, dorsal view; (F) left eyestalk, dorsal view; $(G)$ left antennule and antenna, ventral view; $(H)$ right antennule, ventral view; (I) left third maxilliped and ischium crista dentata, ventral view. Scales equal $1.0 \mathrm{~mm}$. 


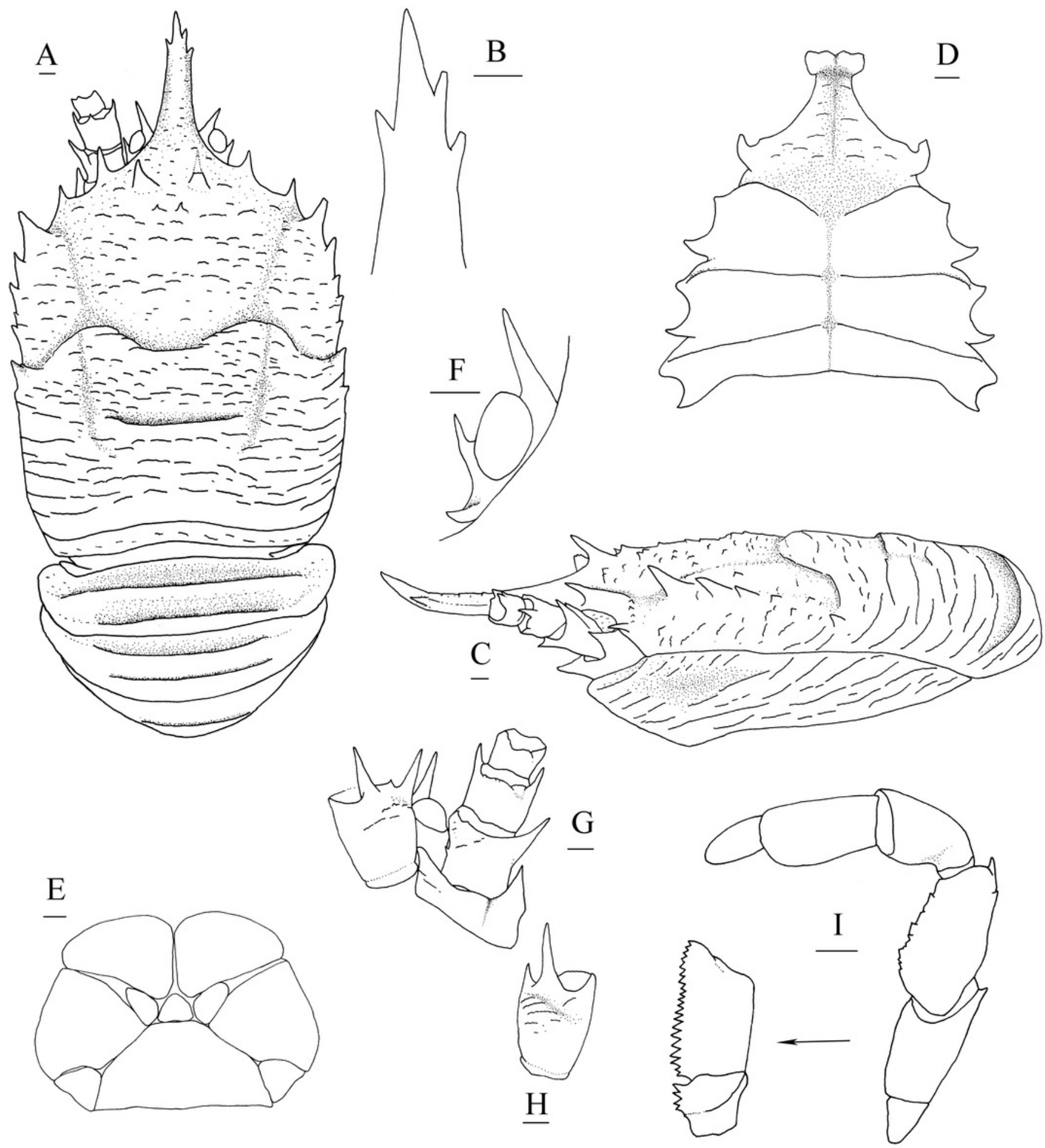




\section{Figure 5}

2nd line drawing of Munidopsis spinifrons

Munidopsis spinifrons sp. nov. SRSIO18100001, holotype. (A) right cheliped (P1), dorsal view (setae only shown on lateral margin of merus); (B) right cheliped (P1), ventral view; (C) right pereopod 2 (P2, with setae), lateral view; (D) right pereopod 3 (P3), lateral view; (E) right pereopod 4 (P4), lateral view; (F) dactylus of right P2, lateral view. Scales equal $1.0 \mathrm{~mm}$.

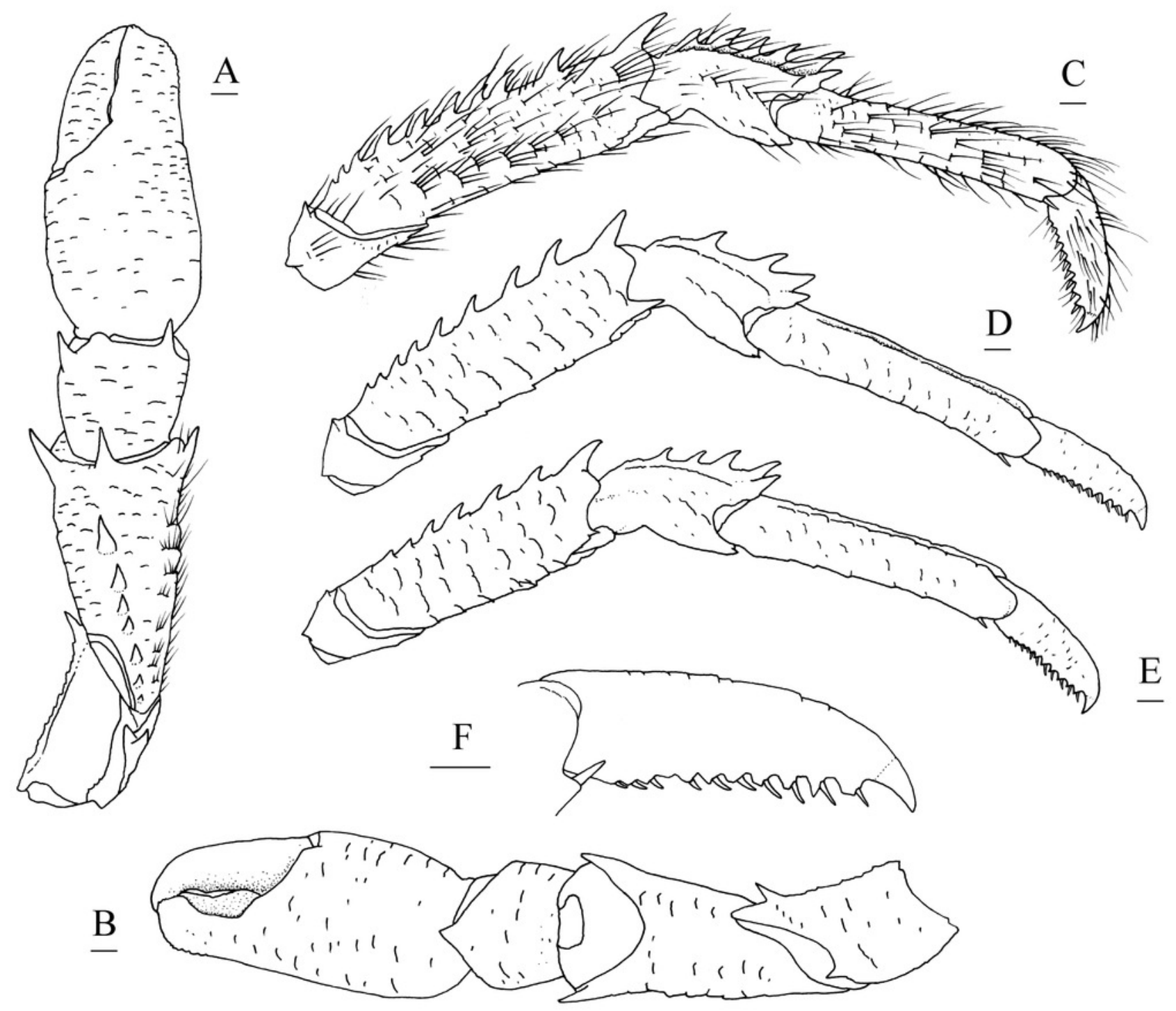


Figure 6

phylogenetic tree

Phylogenetic tree obtained by the Maximum likelihood analysis based on the COI gene sequences. Maximum likelihood bootstrap scores (BP, above) and Bayesian posterior probabilities (PP, below or right) are indicated adjacent to each node. Values of BP $\geq 75 \%$ and $P P \geq 0.95$ are marked red. Only values of $B P \geq 50 \%$ and $P P \geq 0.5$ are shown.

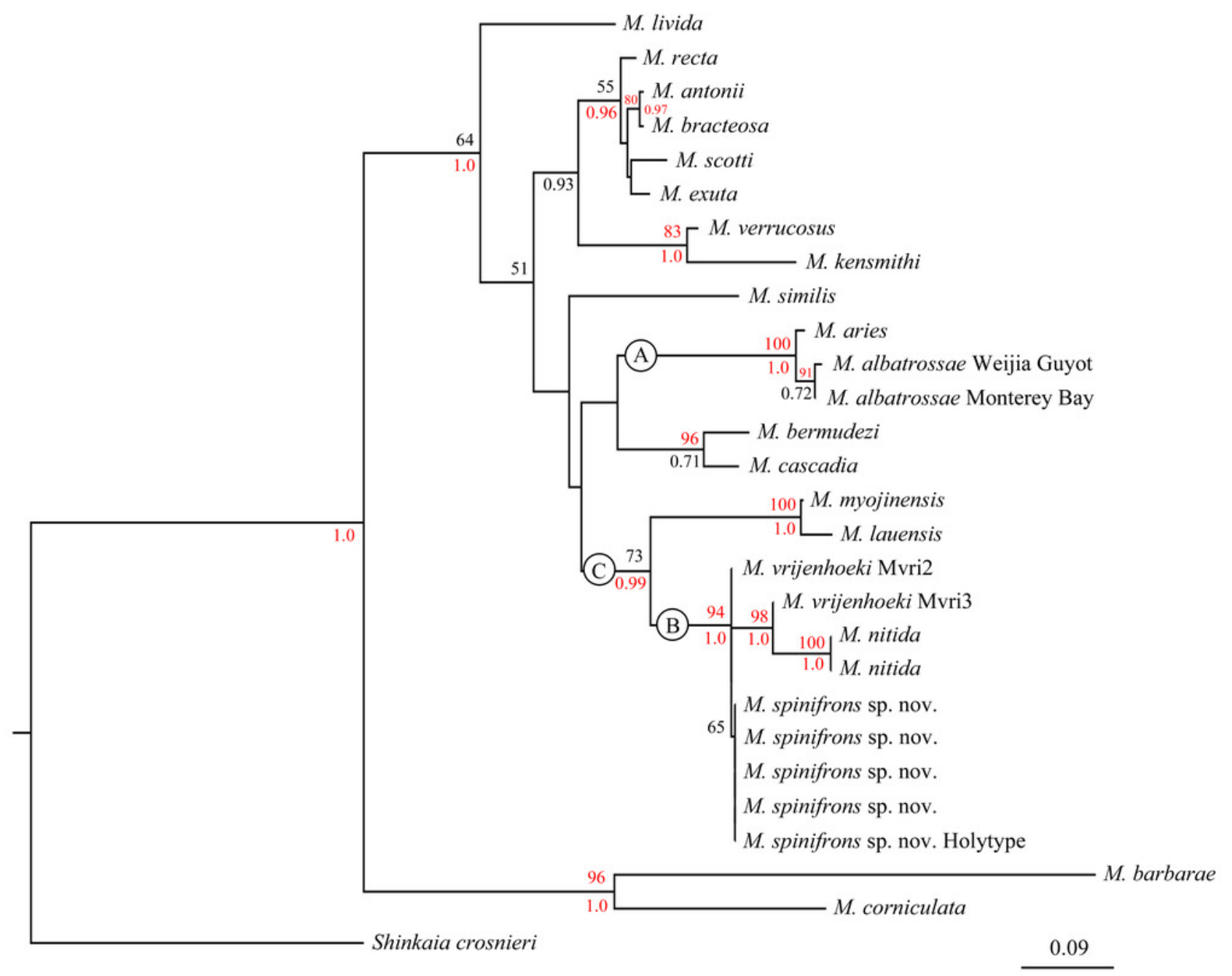

